\title{
Effect of Entrepreneurial Orientation and Family Involvement on Family Business Performance: Case Study in Hotel Business in Yogyakarta
}

\author{
Erny Rachmawati ${ }^{1}$, Pratiwi Dwi Suhartanti ${ }^{2}$ \\ \{ernyunsoed9@gmail.com¹, pratiwi482@gmail.com² \\ ${ }^{1}$ Faculty of Economics and Business, University of Muhammadiyah Purwokerto \\ Purwokerto, Indonesia, ${ }^{2}$ Master of Management, Faculty of Economics and Business, University of \\ Syiah Kuala Banda Aceh, Indonesia
}

\begin{abstract}
This study aims to determine the direct effect of entrepreneurial orientation on family business performance. In addition, this study will also discuss the role of family involvement as a mediating variable. A total of 328 hotels in Yogyakarta were selected as samples by the convenience sampling method. Primary data was collected through a structured questionnaire. Hypotheses are tested by structural equation modeling using AMOS 22.0. Sobel test is used to determine the indirect effect of mediation variables. The results showed that entrepreneurial orientation has no significant effect on family business performance. Family involvement acts as a fully mediation in the relationship between entrepreneurial orientation and family business performance. This finding has significant implications that can help family businesses in developing strategies that are suitable in business management. The results provide a new model in providing an overview of the direct and indirect roles in the assessment of family business performance.
\end{abstract}

Keywords: Entrepreneurial Orientation, Family Involvement, Family Business Performance, Mediating Role, Hotel Business

\section{Introduction}

Several studies have found a very significant role in the family business in a country's economic growth. The family business has contributed greatly to economic activity. Family businesses can contribute between $45 \%$ to $70 \%$ of state income and absorb a lot of labor [34]. In Indonesia, the contribution of family businesses to the formation of GNP is $80 \%$ [29]. Based on National Economic Survey data in 2016, in Indonesia, there were 48,929,636 businesses [14]. Of that amount, as much as $90.95 \%$ can be categorized as a family business. The National Economic Survey Data also states that family businesses contribute $53.28 \%$ of GDP and absorb 85,416,493 people as labor or 96.18\% [39].

At present, unlike non-family businesses that experience ups and downs of growth, family businesses actually show stable performance and tend to increase [53]. One of the factors influencing family business performance is entrepreneurial orientation. In the family business, the courage to take risks is an important dimension in entrepreneurial orientation [16]. Researchers conceptually agree that entrepreneurial orientation encourages superior business performance [8]. Empirical studies find that entrepreneurial orientation has a positive effect on financial performance and non-financial performance of businesses [15]. Other research states 
that entrepreneurial orientation has a positive effect on overall business performance mediated by market orientation [17].

Entrepreneurial orientation are creative, proactive and risk-taking actions in decision making strategies [40]. These dimensions in entrepreneurial orientation have a positive relationship, and have a direct or indirect effect on business profitability [17]. Entrepreneurial orientation is also oriented to more complex business performance, not just financial indicators [5]. The effect of entrepreneurial orientation in family business is determined by the mechanism of knowledge on family members that has an impact on business performance [3]. Family businesses tend to adopt "avoidance" strategies when in crisis conditions, but they can also differ depending on the preferences of family members in taking risks [35].

Family business practices in Indonesia are found by family members who own shares and also participate in business management [33]. In empirical research found negative and significant effect between family involvement on business performance [26]. The family members of the controlling shareholders who act as directors negatively affect business performance in Indonesia. Likewise, family members who directly own shares in the business and simultaneously become directors or commissioners were also found to have a negative effect on business performance. In research on family businesses engaged in non-financial fields in Spain, it was found that family involvement had no significant effect on business performance because family control factors occurred more dominantly so that it could affect performance [28]. Other studies have found that family involvement negatively effects business performance with ROA measures. The results of the study indicate that high family ownership encourages lower performance [16].

However, different from research conducted in the United States on family involvement in ownership structures on business performance, shows the results that family involvement has a positive effect on business performance [45]. Other studies reveal the positive effect of family involvement on business performance [18]. To answer the research gap, this study aims to determine the direct effect of entrepreneurial orientation on family business performance. In addition, this study will also discuss the role of family involvement as a mediating variable in the relationship between entrepreneurial orientation and family business performance.

\section{Literature Review}

\subsection{Relationship about entrepreneurial orientation and family business performance}

Entrepreneurial orientation is an orientation that emphasizes an aggressive orientation regarding products and markets, risky projects, and a tendency to spearhead innovation and lead competition [16]. Entrepreneurial orientation is a selection and learning mechanism that engenders inquiry, risk seeking behavior in product and process innovation [24].

In family business, entrepreneurial orientation determines the relationships and values of the two systems, namely family and business [30]. The effect of entrepreneurial orientation on family business determines long-term vision between generations through developing the capabilities of each family member [19]. In a family business, business performance is a multidimensional concept, where financial and non-financial dimensions are two factors that need to be considered [6]. However, in family businesses, there are concerns that performance appraisals are not only about financial and non-financial aspects, but also to protect the 
continuity of family values in business [13]. In some cases this has a negative effect on business performance [38].

Some researchers have tried to explain the relationship between entrepreneurial orientation and business performance. Entrepreneurial-oriented businesses have the ability to find and exploit new market opportunities [32]. There is a positive relationship between entrepreneurial orientation and profitability and growth of the business [19]. Entrepreneurial orientation and business performance have a significant relationship [30]. However, the results of other studies found no significant relationship between entrepreneurial orientation and business performance [22]. This research will answer the gap between the results of previous studies. Based on the above discussion, the following hypothesis is proposed:

H1. There is a relationship between entrepreneurial orientation and family business performance

\subsection{Relationship about family involvement and family business performance}

Family-owned and managed businesses are a common form that is now often found in many countries [33]. As many as $68 \%$ of the total go-public business in the world is a family ownership company. In Indonesia, the average family ownership is $26 \%$, where this ownership is enough to give the family authority to be involved in managing the performance of the business [55].

Traditionally, family involvement is defined as involving one or more family members who hold a large control over the business, due to a significant percentage of ownership [28]. They explained that family involvement depends on three pillars namely management, family and ownership. Family involvement as management of family businesses by passing on business for generations to get a formal or implicit business vision as a single family property or a small number of families [26]. Family involvement creates an important interconnection bond between business and family [18].

From the perspective of agency theory, family involvement in business management can increase the gap between family and management, especially when there is a mismatch between "family needs" and "business needs". As a consequence, performance appraisal must not be limited to financial performance, but as a whole including non-financial performance. With family involvement, the evaluation of family business performance is different from non-family business [10]. Family businesses tend to choose strategies to achieve business goals based on "family needs" [16]. For family businesses to be able to compete in the global market in the 21 st century, family businesses must expand their stated goals by including benefits that are not only related to financial performance but must be able to compete with non-family businesses [20].

Family involvement is able to bring a positive effect on business performance because the presence of family involvement causes a reduction in agency problems that occur in business. But with family involvement, there is a tendency that businesses will employ relationships in families that do not have enough competence so that they can also negatively affect performance.

Based on the above discussion, the following hypothesis is proposed:

$H 2$ : Family Involvement mediates the relationship between entrepreneurial orientation and family business performance 


\section{Method}

\subsection{Sample and data collection}

This research was conducted in Yogyakarta, Indonesia. The reason for choosing Yogyakarta is because Yogyakarta is a well-known tourism destination city in Indonesia. In 2019 an increase in the number of tourist visits both domestic and foreign as many as $2,181,569$ tourists [14]. This has an effect on increasing the use of accommodations including hotels.

In 2020, there were 1,817 hotels in Yogyakarta [14]. Determination of sample size in a study will largely depend on the uniformity of the population, the analysis techniques used and the availability of funding and the time owned by the researcher [2]. This study adopted the use of sample data collection using a self-delivered questionnaire so that it is expected to get a higher level of truth and return of the questionnaire [58].

Since the total population is known to be 1,817 hotels, using the Slovin formula with the value e $=0.05$, obtained a sample of 328 hotels [47]. All the required samples are distributed proportionally in five districts / cities in Yogyakarta. Thus the number of samples obtained in each district / city as described in Table 1:

Table 1. Sample

\begin{tabular}{ccccc}
\hline Regency/Municipality & Classified & Non-Classified & Population & Sample \\
\hline Kulonprogo & 0 & 25 & 25 & 5 \\
Bantul & 2 & 313 & 315 & 57 \\
Gunung kidul & 2 & 198 & 200 & 36 \\
Sleman & 61 & 643 & 704 & 127 \\
Yogyakarta City & 98 & 475 & 573 & 103 \\
Total & 163 & 1654 & 1817 & 328 \\
\hline Source: Hotels Survey (Special Region of Yogyakarta in Figures, 2020) [14]
\end{tabular}

After completing the selection of respondents, researchers contact respondents to convey the intent of the research conducted. The data were collected in January 2020 to March 2020. Respondents from this study were key people at the hotel such as owners, directors, and key staff (HRD, financial, relationship).

This research focuses on primary data collected through structured questionnaires developed and adapted from the existing literature. Scales were measured using a 7 Likert type scale (1 represent strongly disagree and 7 represent strongly agree). Entrepreneurial Orientation Dimensions EO1 - EO10 [28]. The dimensions of entrepreneurial orientation are classified into 3 dimensions, namely innovativeness, risk taking and proactiveness. Family Involvement Dimensions FI1 - FI8 [33]. Family Business Performance Dimensions FBP1 FBP10 [53]. The FBP dimension uses non-financial performance indicators which are classified into 3 dimensions, namely the efficiency dimension (room occupancy rate, tum over interval, roomboy productivity level, tum over employee), quality dimension (level of guest complaints, level of returning guests), time dimension ( average length of stay of guests, check-in and check-out service time, room cleaning service time). 


\subsection{Data analysis}

Demographic characteristics of respondents will be processed using IBM SPSS 22. Furthermore, this study adopts a two-stage approach proposed by Anderson and Gerbing (1988) for structural equation modeling (SEM), namely the first stage to test the research framework and the second stage to test the research hypotheses [7]. The Sobel test is used to test the significance of the indirect effect of the independent variable on the dependent variable through the mediating variable [50]. By using the sobel test, it can be determined whether the family involvement variable acts as a mediating variable in the relationship between entrepreneurial orientation and family business performance [42].

\section{Results And Discussion}

\subsection{Demographic characteristics}

Analysis of demographic characteristics is very important to obtain personal data information from research respondents. The aim is to justify the level of representation of the target population. Demographic characteristics are divided into two, namely hotel characteristics and respondent characteristics. The hotel characteristics include: owner's gender and hotel age. Respondent characteristics include: position, respondent's gender, marital status, age, education level and length of work. Demographic characteristics are explained in Table 2.

Table 2. Demographic characteristic

\begin{tabular}{ccc}
\hline Demographic factors & Frequency & (\%) \\
\hline Hotel Characteristic & & \\
\hline Owner gender & & \\
Male & 202 & 61.6 \\
Female & 126 & 38.4 \\
Hotel age (year) & & \\
$1-5$ & 61 & 18.6 \\
$6-10$ & 113 & 34.5 \\
$11-15$ & 53 & 16.2 \\
$16-20$ & 47 & 14.3 \\
$21-25$ & 35 & 10.7 \\
Above 25 & 19 & 5.7 \\
\hline Respondent Characteristic & & \\
Position & & \\
Owner & & \\
Director & 213 & 64.9 \\
Staff (HRD, & 73 & 22.3 \\
financial, & 42 & 12.8 \\
relationship) & & \\
Gender & & \\
Male & 171 & 52.1
\end{tabular}




\begin{tabular}{ccc} 
Female & 157 & 47.9 \\
Marital Status & & \\
Single & 91 & 27.7 \\
Married & 237 & 72.3 \\
Age (year) & & \\
$21-30$ & 51 & 15.6 \\
$31-40$ & 96 & 29.3 \\
$41-50$ & 143 & 43.6 \\
Above 50 & 38 & 11.5 \\
Education Level & & \\
Lower Level & 87 & 26.5 \\
Upper Level & 241 & 73.5 \\
Length of Work & & \\
(year) & & \\
$1-5$ & 50 & 15.2 \\
$6-10$ & 139 & 42.4 \\
$11-15$ & 65 & 19.8 \\
$16-20$ & 37 & 11.3 \\
$21-25$ & 26 & 7.9 \\
Above 25 & 11 & 3.4 \\
\hline Source : Primary Data (2020) &
\end{tabular}

\subsection{Model Testing}

Confirmatory factor analysis (CFA) is used to test the validity of the questionnaire. After the validation test, there are four indicators that have an estimated value $<0.5$, namely EO9, EO10, FI7 and FBP5. So that these four indicators will be removed from the model. After modification, all indicators used are valid because they have an estimated standardized regression weights $>0.5$. Then, a reliability test is carried out to determine whether the questionnaire can be used more than once. From the analysis it can be seen that in the output square multiple correlation all indicators have an estimate value above 0.600. Because the value is greater than 0.600 , the questionnaire measurement tool is reliable or meets the reliability requirements. In this study, goodness of fit test results can be seen that the value of $\mathrm{CMIN} / \mathrm{DF}=2.314, \mathrm{GFI}=0.927, \mathrm{AGFI}=0.931, \mathrm{PGFI}=0.756, \mathrm{NFI}=0.972, \mathrm{IFI}=0.930$, $\mathrm{TLI}=0.958, \mathrm{CFI}=0.972$ and RMSEA $=0.072$. The result of the confirmatory factor analysis revealed the model with good fit, so the model was appropriate and could be continued for further analysis. 


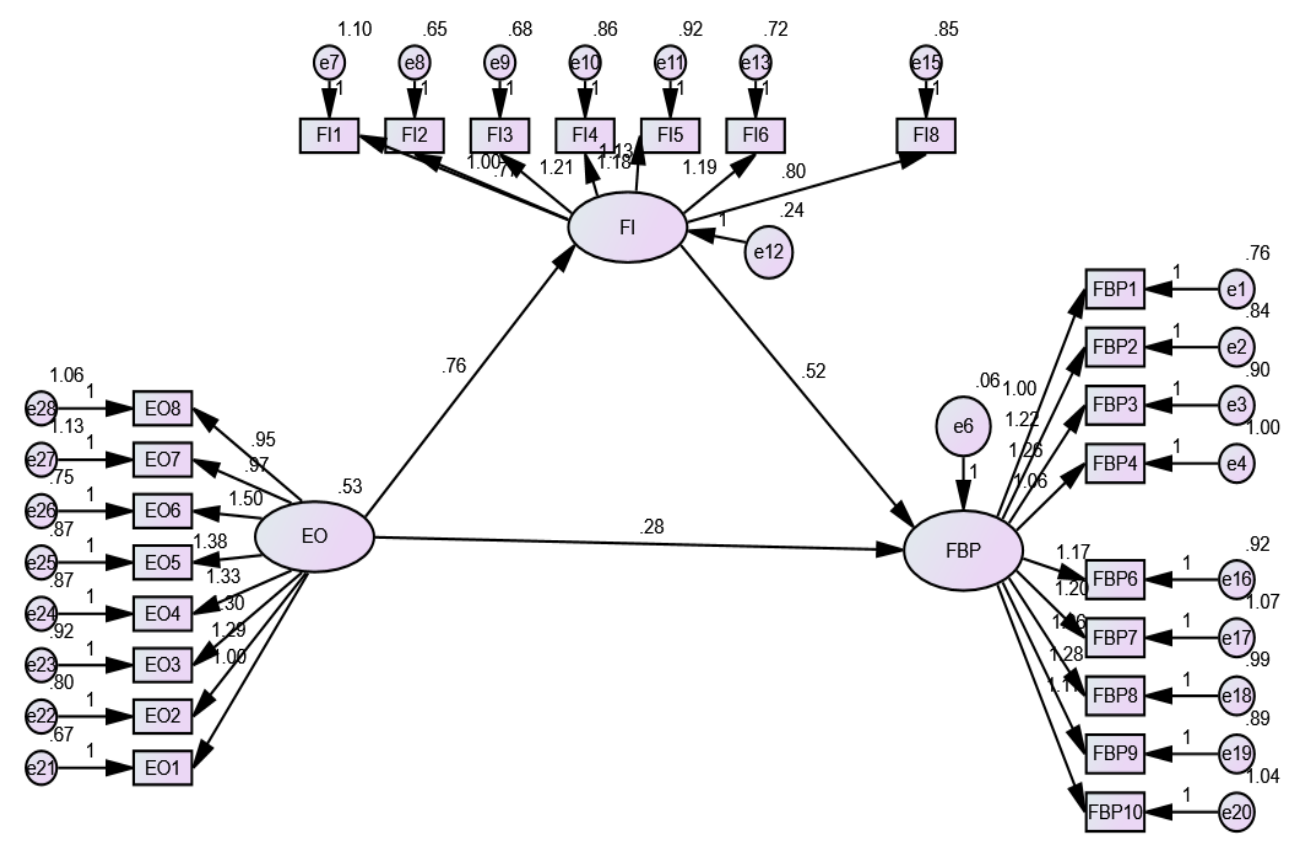

Fig. 1. Path Diagram

\subsection{Hypothesis testing}

a) Testing the hypothesis of direct effect between variables

After overall a structural model can be considered fit, the next process is to see whether there is a significant effect between the independent variable and the dependent variable. Testing this hypothesis is done by looking at the estimated results of the research model. Basic decision making [27] i.e. CR value $>1.96$ and $\mathrm{P}$ value $<0.05$ then the hypothesis is not rejected meaning that the variable has a significant effect, whereas if the value of $\mathrm{CR}<$ 1.96 and $\mathrm{P}$ value $>0.05$ then the hypothesis is rejected means that the variable has no effect. The estimation results of the model can be seen in Table 3.

Table 3. Model estimation results

\begin{tabular}{|c|c|c|c|c|c|c|}
\hline \multicolumn{3}{|c|}{ Hypothesis } & \multirow{2}{*}{$\begin{array}{c}\text { Estimate } \\
.518\end{array}$} & \multirow{2}{*}{$\begin{array}{l}\text { S.E. } \\
.089\end{array}$} & \multirow{2}{*}{$\begin{array}{l}\text { C.R. } \\
2.589\end{array}$} & \multirow{2}{*}{$\begin{array}{c}\mathrm{P} \\
* * *\end{array}$} \\
\hline FBP & $<---$ & FI & & & & \\
\hline FI & $<---$ & EO & .761 & .093 & 4.451 & $* * *$ \\
\hline FBP & $<---$ & EO & .277 & .067 & 2.873 & .068 \\
\hline \multirow{2}{*}{\multicolumn{7}{|c|}{$\begin{array}{l}\text { Notes: } \\
\text { S.E: Standard errors; C.R: Critical ratio; P: Probabality (*** } \\
\text { p is significant at } 0.01 \text { level). }\end{array}$}} \\
\hline & & & & & & \\
\hline \multicolumn{7}{|c|}{$\begin{array}{l}\text { FBP: Family Business Performance; FI: Family } \\
\text { Involvement; EO: Entrepreneurial Orientation. }\end{array}$} \\
\hline
\end{tabular}

Hypothesis 1 : There is a relationship between entrepreneurial orientation and family business performance. Not Rejected. This is because the CR value is 2,873 (CR $\geq 1.96$ ). But 
the effect is not significant because the probability value of 0.068 or greater than 0.05 . The results of this study are different from the results of previous studies, that entrepreneurial orientation has a significant effect on family business performance [3] [5] [8] [9] [16] [17] [40]. Significance occurs because of the effect of family involvement on entrepreneurial orientation [33] [54]. So the role of family involvement in mediating the relationship between entrepreneurial orientation and family business performance will be further discussed.

b) Testing the hypothesis of mediating effect between variables

To find out whether the indirect effect of $\mathrm{X}$ to $\mathrm{Z}$ through $\mathrm{Y}$ is significant or not, a Sobel test was performed. Sobel test is used to determine the indirect effect of mediation variables [50]. Sobel Test is a test to find out whether a relationship through a mediating variable is significantly capable as a mediator in that relationship [4]. Hypothesis is not rejected if this calculation produces a value of $z \geq 1.98$ with a significance level $\leq 0.05$ [42] [51]. Sobel test results can be seen in Table 4.

Table 4. Sobel testing

\begin{tabular}{|c|c|c|c|c|c|c|}
\hline & A & $\mathrm{B}$ & SEA & SEB & Zvalue & $p$-value \\
\hline EO to FBP through FI & 0.761 & 0.518 & 0.093 & 0.089 & 4.74 & $* * *$ \\
\hline \multicolumn{7}{|c|}{$\begin{array}{l}\text { Notes: } \\
\text { EO: Entrepreneurial Orientation; FI: Family Involvement; FBP: Family Business } \\
\text { Performance. } \\
\text { A: Raw (unstandardized) regression coefficient for the association between } \\
\text { independent variable and mediator; B: Raw coefficient for the association between } \\
\text { the mediator and the dependent variable (when the independent variable is also a } \\
\text { predictor of the dependent variable); SEA: standard error of A; SEB: standard error } \\
\text { of B; Zvalue: Sobel value; } p \text {-value: probability }(* * * \leq 0.01)\end{array}$} \\
\hline
\end{tabular}

Hypothesis 2 : Family Involvement mediates the relationship between entrepreneurial orientation and family business performance. Not Rejected. From the calculation of the sobel test the effect of EO on FBP through FI obtained a $\mathrm{z}$ value of 4.74 . Because the $\mathrm{z}$ value obtained is $2.74>1.98$ with a significance level of $* * *$ or $\leq 0.01$, it proves that FI is significantly able to mediate the relationship between the effect of EO on FBP. From the results of the direct effect hypothesis it is known that EO has no significant effect on FBP. With the FI, the relationship between EO and FBP through FI becomes significant. So it can be concluded that FI has a role as fully mediated in the relationship between EO and FBP. 


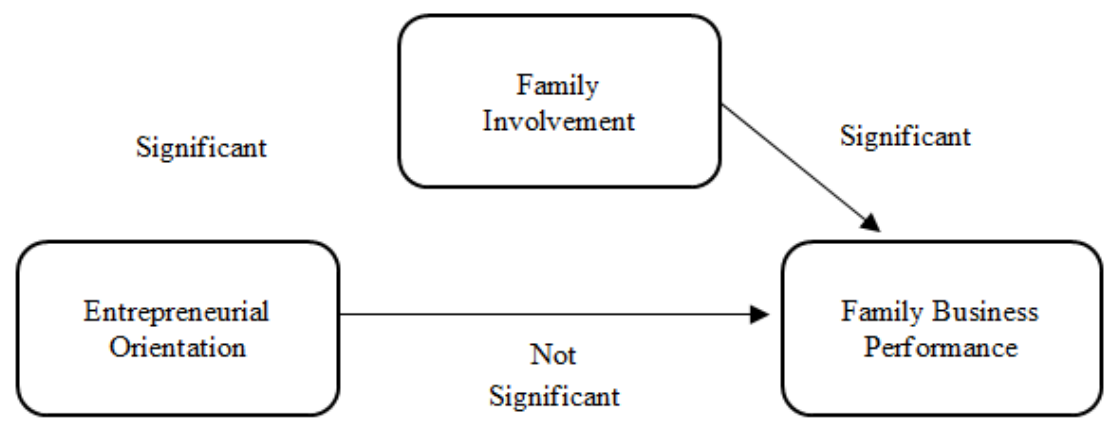

Fig.2. Mediating Role of Family Involvement on Relationship Between Entrepreneurial Orientation and

Family Business Performance

The results of this study provide a new model in providing an overview of the direct and indirect roles in the assessment of family business performance. This study uses three variables which are important variables in performance appraisal, namely entrepreneurial orientation (independent variable) and family involvement (mediating variable). The results showed that entrepreneurial orientation had no significant effect on family business performance. However, the relationship between entrepreneurial orientation and family business performance is significant by being mediated by family involvement. The results of this study indicate support for previous research.

By investigating the entrepreneurial orientation of the company, it can be explained that there is a managerial process that enables the company to reach a position that is superior to its competitors, because the entrepreneurial orientation facilitates the company's actions to act on initial signs originating from the company's internal and external environment [52]. Entrepreneurial orientation leads to the strategic orientation of a company, including aspects of the style, methods and practices of specific entrepreneurial decision making. Entrepreneurial orientation can be an important measurement of how a company is organized, and is an important entrepreneurial contribution to company performance. Entrepreneurial orientation can "enrich the performance benefits of the company's knowledge-based resources by paying attention to the use of these resources to uncover and exploit opportunities".

The success of a family business is largely determined by its leader [25]. A leader who has the knowledge, skills and new ideas that can be contributed is the most important factor in the formulation of business strategies and decision making [23] [37] [44]. Thus, the contribution of leaders depends on their level of orientation and strategic involvement in the business being managed [12] [21].

The effect of family business performance on business continuity is enormous. In general, family businesses involve owners, family members and hotel management (who come from outside the family) [1] [11] [18] [41] [46]. In some cases, the family acts as both the owner and management [17] [43]. But in other cases that management also comes from outside family members [11] [18]. So that the involvement between the owner, family members and management becomes an important measure of the success of a hotel managed by a family business. Family business depends on the involvement of the family to become part of the 
local community making it easier for hotel management to gain knowledge of the local culture that allows the achievement of profitable profits [26].

In addition, entrepreneurs who have a high entrepreneurial orientation can improve business performance [36] [49]. Entrepreneurs involved in the local community can provide authentic experiences to tourists based on their own knowledge. The effectiveness of community involvement is effectd by politics and local relations, as well as the personal skills of the owner [48]. One form of community involvement is to employ local residents. This can build strong social capital in local communities that can enhance and support local businesses in the tourism sector. So that it can indirectly support and effect the future goals of business practices and long-term strategies for small business owners in the tourism sector [13] [31]. At the same time assisting the government in increasing Local Revenue and increasing the standard of living of the people in the region, especially in tourism destinations.

\section{Conclusion}

There are two limitations to this study as follows: the results of the study cannot conclude a national family business: this study adopts convenience sampling and the sampling area is limited in Yogyakarta. From the perspective of statistical theory, the sample may lack the generalization power, and may not be suitable for inference as a citizen in general. The results of the study are not conclusive for family business in general. This study only conducts research on hotels managed by family businesses. Despite obtaining concrete conclusions, the results of research may not be suitable for conclusions on family business in general.

This finding has significant implications that can help family businesses in developing strategies that are suitable in business management. Entrepreneurial orientation occupies a strategic position in developing sustainable competitive advantage in the family business of the tourism sector especially the hotel business in Yogyakarta for the better. Family businesses need to be committed to innovation, proactivity, courage in taking risks and being able to manage risk.

In addition, the results of the study also showed that entrepreneurial orientation had no significant effect on performance. This relationship becomes significant when combined with active family involvement. This finding also shows that entrepreneurial orientation has the potential to have a more beneficial effect because of the active involvement of the family in helping with business management, alleviating business-related problems and having a significant effect when the family also acts as management.

This study only conducts research on family business hotels in Yogyakarta. Future research may choose to use several types of family businesses so that more varied results can be obtained. Future research could also compare hotels managed by family businesses with non-family businesses. The results found that the heterogeneity of respondents was an important component in the study of social identity. Therefore, research examining the effect of different cultures on the relationship between entrepreneurial orientation and family business performance should be an extraordinary topic for future study because this will help broaden the theory of social identity and social capital. In this study, researchers used a questionnaire survey to verify hypotheses, thus only providing cross-sectional data. For future research longitudinal studies need to be done to see the dynamic changes between generations to the next generation in family business. 


\section{References}

[1] Abdullah A. Al-Dubai, S., Nor Izah Ku Ismail, K., \& Afza Amran, N. (2014). Family involvement in ownership, management, and firm performance: Moderating and direct-effect models. Asian Social Science. https://doi.org/10.5539/ass.v10n14p193

[2] Agarwal, J., \& Malhotra, N. K. (2005). An integrated model of attitude and affect: Theoretical foundation and an empirical investigation. Journal of Business Research. https://doi.org/10.1016/S0148-2963(03)00138-3

[3] Akhtar, C. S., Ismail, K., Hussain, J., \& Umair-Ur-rehman, M. (2015). Investigating the moderating effect of family on the relationship between Entrepreneurial orientation and success of enterprise: Case of Pakistani manufacturing SMEs. International Journal of Entrepreneurship and Small Business. https://doi.org/10.1504/IJESB.2015.071825

[4] Allen, M. (2017). Sobel Test. In The SAGE Encyclopedia of Communication Research Methods. https://doi.org/10.4135/9781483381411.n570

[5] Aloulou, W. J. (2018). Examining entrepreneurial orientation's dimensions - performance relationship in Saudi family businesses: Contingency role of family involvement in management. Journal of Family Business Management. https://doi.org/10.1108/JFBM-02-2018-0007

[6] Anderson, B. S., Kreiser, P. M., Kuratko, D. F., Hornsby, J. S., \& Eshima, Y. (2015). Reconceptualizing entrepreneurial orientation. Strategic Management Journal. https://doi.org/10.1002/smj.2298

[7] Anderson, J. C., \& Gerbing, D. W. (1988). Structural Equation Modeling in Practice: A Review and Recommended Two-Step Approach. Psychological Bulletin. https://doi.org/10.1037/00332909.103.3.411

[8] Arzubiaga, U., Iturralde, T., Maseda, A., \& Kotlar, J. (2018). Entrepreneurial orientation and firm performance in family SMEs: the moderating effects of family, women, and strategic involvement in the board of directors. International Entrepreneurship and Management Journal. https://doi.org/10.1007/s11365-017-0473-4

[9] Arzubiaga, U., Kotlar, J., De Massis, A., Maseda, A., \& Iturralde, T. (2018). Entrepreneurial orientation and innovation in family SMEs: Unveiling the (actual) impact of the Board of Directors. Journal of Business Venturing. https://doi.org/10.1016/j.jbusvent.2018.03.002

[10] Basco, R., \& Pérez Rodríguez, M. J. (2011). Ideal types of family business management: Horizontal fit between family and business decisions and the relationship with family business performance. Journal of Family Business Strategy. https://doi.org/10.1016/j.jfbs.2011.07.004

[11] Bauweraerts, J., \& Colot, O. (2017). Exploring nonlinear effects of family involvement in the board on entrepreneurial orientation. Journal of Business Research. https://doi.org/10.1016/j.jbusres.2016.08.020

[12] Bertrand, M., Johnson, S., Samphantharak, K., \& Schoar, A. (2008). Mixing family with business: A study of Thai business groups and the families behind them. Journal of Financial Economics. https://doi.org/10.1016/j.jfineco.2008.04.002

[13] Boso, N., Story, V. M., \& Cadogan, J. W. (2013). Entrepreneurial orientation, market orientation, network ties, and performance: Study of entrepreneurial firms in a developing economy. Journal of Business Venturing. https://doi.org/10.1016/j.jbusvent.2013.04.001 
[14] BPS-Statistics Indonesia. (2020). Statistik Indonesia. Statistical Yearbook of Indonesia. https://doi.org/10.3389/fpsyg.2015.00002

[15] Campopiano, G., Brumana, M., Minola, T., \& Cassia, L. (2019). Does Growth Represent Chimera or Bellerophon for a Family Business? The Role of Entrepreneurial Orientation and Family Influence Nuances. European Management Review. https://doi.org/10.1111/emre.12351

[16] Casillas, Jose C., Moreno, A. M., \& Barbero, J. L. (2010). A configurational approach of the relationship between entrepreneurial orientation and growth of family firms. Family Business Review. https://doi.org/10.1177/0894486509345159

[17] Casillas, José C., Moreno, A. M., \& Barbero, J. L. (2011). Entrepreneurial orientation of family firms: Family and environmental dimensions. Journal of Family Business Strategy. https://doi.org/10.1016/j.jfbs.2011.03.002

[18] Cherchem, N. (2017). The relationship between organizational culture and entrepreneurial orientation in family firms: Does generational involvement matter? Journal of Family Business Strategy. https://doi.org/10.1016/j.jfbs.2017.04.001

[19] Cho, Y. H., \& Lee, J.-H. (2018). Entrepreneurial orientation, entrepreneurial education and performance. Asia Pacific Journal of Innovation and Entrepreneurship. https://doi.org/10.1108/apjie-05-2018-0028

[20] Chrisman, J. J., Chua, J. H., \& Steier, L. P. (2003). An introduction to theories of family business. In Journal of Business Venturing. https://doi.org/10.1016/S0883-9026(03)00052-1

[21] Chua, J. H., Chrisman, J. J., \& Sharma, P. (1999). Defining the Family Business by Behavior. Entrepreneurship Theory and Practice. https://doi.org/10.1177/104225879902300402

[22] Covin, J. G., \& Lumpkin, G. T. (2011). Entrepreneurial orientation theory and research: Reflections on a needed construct. Entrepreneurship: Theory and Practice. https://doi.org/10.1111/j.15406520.2011.00482.x

[23] Craig, J., \& Dibrell, C. (2006). The natural environment, innovation, and firm performance: A comparative study. Family Business Review. https://doi.org/10.1111/j.1741-6248.2006.00075.x

[24] Dai, L., Maksimov, V., Gilbert, B. A., \& Fernhaber, S. A. (2014). Entrepreneurial orientation and international scope: The differential roles of innovativeness, proactiveness, and risk-taking. Journal of Business Venturing. https://doi.org/10.1016/j.jbusvent.2013.07.004

[25] Danes, S. M., \& Olson, P. D. (2003). Women's Role Involvement in Family Businesses, Business Tensions, and Business Success. Family Business Review. https://doi.org/10.1111/j.17416248.2003.00053.x

[26] Dyer, W. G. (2006). Examining the "family effect"on firm performance. Family Business Review. https://doi.org/10.1111/j.1741-6248.2006.00074.x

[27] Hair, J., Black, W., Babin, B., \& Anderson, R. (2010). Multivariate Data Analysis: A Global Perspective. In Multivariate Data Analysis: A Global Perspective.

[28] Hansen, C., \& Block, J. (2020). Exploring the relation between family involvement and firms' financial performance: A replication and extension meta-analysis. Journal of Business Venturing Insights. https://doi.org/10.1016/j.jbvi.2020.e00158

[29] Hasbi, H. (2015). Islamic Microfinance Institution: The Capital Structure, Growth, Performance and Value of Firm in Indonesia. Procedia - Social and Behavioral Sciences. https://doi.org/10.1016/j.sbspro.2015.11.143

[30] Huang, S. K., \& Wang, Y. L. (2011). Entrepreneurial orientation, learning orientation, and innovation in small and medium enterprises. Procedia - Social and Behavioral Sciences. 
https://doi.org/10.1016/j.sbspro.2011.09.004

[31] Javalgi, R. G., \& Todd, P. R. (2011). Entrepreneurial orientation, management commitment, and human capital: The internationalization of SMEs in India. Journal of Business Research. https://doi.org/10.1016/j.jbusres.2010.11.024

[32] Keh, H. T., Nguyen, T. T. M., \& Ng, H. P. (2007). The effects of entrepreneurial orientation and marketing information on the performance of SMEs. Journal of Business Venturing. https://doi.org/10.1016/j.jbusvent.2006.05.003

[33] Kellermanns, F. W., Eddleston, K. A., Barnett, T., \& Pearson, A. (2008). An exploratory study of family member characteristics and involvement: Effects on entrepreneurial behavior in the family firm. Family Business Review. https://doi.org/10.1111/j.1741-6248.2007.00107.x

[34] Kwon, S. W., \& Ruef, M. (2017). The imprint of labor markets on entrepreneurial performance. Journal of Business Venturing. https://doi.org/10.1016/j.jbusvent.2017.08.002

[35] Lee, T., \& Chu, W. (2017). The relationship between entrepreneurial orientation and firm performance: Influence of family governance. Journal of Family Business Strategy. https://doi.org/10.1016/j.jfbs.2017.09.002

[36] Lumpkin, G. T., \& Dess, G. G. (1996). Clarifying the entrepreneurial orientation construct and linking it to performance. Academy of Management Review. https://doi.org/10.5465/AMR.1996.9602161568

[37] Mahto, R. V., Davis, P. S., Pearce, J. A., \& Robinson, R. B. (2010). Satisfaction with firm performance in family businesses. Entrepreneurship: Theory and Practice. https://doi.org/10.1111/j.1540-6520.2010.00393.x

[38] Matsuno, K., Mentzer, J. T., \& Özsomer, A. (2002). The effects of entrepreneurial proclivity and market orientation on business performance. Journal of Marketing. https://doi.org/10.1509/jmkg.66.3.18.18507

[39] Meutia, \& Ismail, T. (2012). The Development of Entrepreneurial Social Competence and Business Network to Improve Competitive Advantage and Business Performance of Small Medium Sized Enterprises: A Case Study of Batik Industry in Indonesia. Procedia - Social and Behavioral Sciences. https://doi.org/10.1016/j.sbspro.2012.11.089

[40] Naldi, L., Nordqvist, M., Sjöberg, K., \& Wiklund, J. (2007). Entrepreneurial orientation, risk taking, and performance in family firms. Family Business Review. https://doi.org/10.1111/j.17416248.2007.00082.x

[41] Poutziouris, P., Savva, C. S., \& Hadjielias, E. (2015). Family involvement and firm performance: Evidence from UK listed firms. Journal of Family Business Strategy. https://doi.org/10.1016/j.jfbs.2014.12.001

[42] Preacher, K. J., \& Leonardelli, G. J. (2001). Calculation for the Sobel test. Retrieved September.

[43] Revilla, A. J., Pérez-Luño, A., \& Nieto, M. J. (2016). Does Family Involvement in Management Reduce the Risk of Business Failure? The Moderating Role of Entrepreneurial Orientation. Family Business Review. https://doi.org/10.1177/0894486516671075

[44] Schepers, J., Voordeckers, W., Steijvers, T., \& Laveren, E. (2014). The entrepreneurial orientationperformance relationship in private family firms: The moderating role of socioemotional wealth. Small Business Economics. https://doi.org/10.1007/s11187-013-9533-5

[45] Sciascia, S., \& Mazzola, P. (2008). Family Involvement in Ownership and Management: Exploring Nonlinear Effects on Performance. Family Business Review. https://doi.org/10.1111/j.17416248.2008.00133.x 
[46] Sciascia, S., Mazzola, P., \& Chirico, F. (2013). Generational Involvement in the Top Management Team of Family Firms: Exploring Nonlinear Effects on Entrepreneurial Orientation. Entrepreneurship: Theory and Practice. https://doi.org/10.1111/j.1540-6520.2012.00528.x

[47] Sekaran, U. (2012). Research Methods for Business Research Methods for Business. In Research methods for business. https://doi.org/10.13140/RG.2.1.1419.3126

[48] Shan, P., Song, M., \& Ju, X. (2016). Entrepreneurial orientation and performance: Is innovation speed a missing link? Journal of Business Research. https://doi.org/10.1016/j.jbusres.2015.08.032

[49] Slater, S. F., \& Narver, J. C. (1995). Market Orientation and the Learning Organization. Journal of Marketing. https://doi.org/10.2307/1252120

[50] Sobel, M. E. (1987). Direct and Indirect Effects in Linear Structural Equation Models. Sociological Methods \& Research. https://doi.org/10.1177/0049124187016001006

[51] Solimun, \& Fernandes, A. A. R. (2017). Investigation the mediating variable: What is necessary? (case study in management research). International Journal of Law and Management. https://doi.org/10.1108/IJLMA-09-2016-0077

[52] Wiklund, J., \& Shepherd, D. (2005). Entrepreneurial orientation and small business performance: A configurational approach. Journal of Business Venturing. https://doi.org/10.1016/j.jbusvent.2004.01.001

[53] Williams, R. I. (2018). Measuring family business performance: research trends and suggestions. Journal of Family Business Management. https://doi.org/10.1108/JFBM-12-2017-0047

[54] Williams, R. I., Pieper, T., Kellermanns, F., \& Astrachan, J. (2019). Applying an organizational effectiveness approach to measure family business performance. Journal of Family Business Management. https://doi.org/10.1108/JFBM-01-2019-0002

[55] Yudha, D. P., \& Singapurwoko, A. (2017). The effect of family and internal control on family firm performance: Evidence from Indonesia Stock Exchange (IDX). Journal of Business and Retail Management Research. https://doi.org/10.24052/jbrmr/v11is04/teofaicoffpefise

[58] Zikmund, Babin, Carr, \& Griffin. (2009). Sampling Designs and Sampling Procedures. Business Research Methods. 